Sun, Moon and Stars

Astronomy for Beginners. By Prof. William T. Skilling and Robert S. Richardson. (Whittlesey House Publication.) Pp. viii + 274. (New York and London : McGraw-Hill Book Co., Inc., 1946.) 12s. $6 d$.

7 HE authors of this book are well equipped for producing a work that will appeal to young people-and one might add to older people, too, who have little or no scientific background. Prof. Skilling has taught astronomy for many years and Dr. Richardson, at present associated with the Mount Wilson Observatory, has devoted a number of years to research. Five parts deal in turn with "The Moon", "The Sun", "The Sun's Family of Planets", "The Stars", and "Astronomers and Observatories", and the subjects are treated in a manner which requires practically no mathematics, or where such is introduced, it is of the most elementary character. The descriptions are excellent for the readers for whom the book is intended, and are illustrated by ninety-nine diagrams and photographs.

The work has been produced primarily for American readers, but it will probably have a good circulation among British readers as well. For this reason it is suggested that a new edition might contain certain amendments where the text is directed specifically to American readers and may mislead others (pp. 48 , $109,165)$.

A few other points require attention. The reference to the rising of the full moon in September (p. 37) does not apply for all latitudes; and the old theory about the apparent enlargement of the moon when close to the horizon (p. 42) is no longer held. The corona can now be seen without a total solar eclipse (p. 87). It might be inferred (p. 107) that the tidal theory of the origin of the solar system is generally accepted, but it would be more correct to say that it was generally rejected; and the view that swift meteors are hyperbolic (p. 164) is no longer held. These are very minor blemishes which do not detract from the value of a most readable and informative book.

M. Davidson

\section{Exploring Nature with a Camera}

By Ernest G. Neal. Pp. $103+62$ plates. (London : Paul Elek (Publishers), Ltd., 1946.) 10s. 6d. net.

$\mathrm{B}$ IRD photography has reached such a pitch of excellence, its devotees are so many and so enthusiastic, that we are apt to forget that the camera is a useful aid in many other branches of field work. In "Exploring Nature with a Camera", Mr. E. G. Neal makes this clear. He deals, it is true, with the photography of birds, but he devotes as much or more space to insect photography, night photography, plant photography and so on. His chapter on night work is illustrated by some good flashlight pictures of badgers near their sett, and we envy him the thrill of taking them. The author says in his preface that "this book is written in the hope that the keen naturalist who has got a camera, especially those of the younger generation, will be encouraged to try it out,', and it can be highly recom. mended as a present for the beginner. Although Mr. Neal says his little volume "is not a technical book on photography", it is full of practical informa. tion on the use of the camera (not forgetting his hints on the type of instrument) and how to take pictures of birds, mammals, insects, reptiles, flowers, fungi, etc. Here and there, as if by accident, interesting observations are recorded. Commenting that it is often easier to photograph a portion of an object than the whole, say a few twigs rather than the whole tree, he gives as an instance ice-encased twigs during the great 'crystal thaw' of 1939-40, when trees, bushes and other vegetation were thickly coated with clear ice. Then, as an aside, he remarks, "I was interested to see a wych elm tree with the usual covering of ice, for I knew that the white letter hairstreak butterfly (Strymon w-album) laid its eggs every year on the twigs of this particular tree, and that they would now be encased in ice. The following July this species was more common than for many years, so the ice had no appreciable bad effect."

Frances PitT

\section{Insects of the Pacific World}

By C. H. Curran. (Pacific World Series.) Pp. xvi+ $317+8$ plates. (New York: The Macmillan Company ; London: Macmillan and Co., Ltd., 1945.) 15s. net.

7 HIS book is intended as an elementary guide to the insect life on the numerous islands, large and small, of the Pacific Ocean- "from the Galapagos and Hawaii to New Zealand, Sumatra and Burma, and in the area from Australia to Formosa, Japan and the Aleutians". It is a plain, readable account, taking the insects of each order, family by family. Beginning with the true flies, it passes in descending sequence to the Orthoptera and Apterygota. At the end of the book there are brief chapters on the Arachnida and their allies (by W. J. Gertsch), on insects and disease and, finally, instructions on preserving and collecting insects. For the most part the book deals with its subject in very general terms, and says singularly little about individual Pacific insects. Even the well-known elements in the fauna of Hawaii and New Guinea scarcely receive mention. But, as the author remarks, what chance is there to say much about so many insects of which so little is known. The size of the book, indeed, limits the treatment severely. The text-figures and plates are good and, apart from misspellings on pp. 13, 140 and 141 , and an erroneous account of Cactoblastis on p. 149, the book will aid the beginner who may visit the vast area under consideration. A. D. I.

Esquisse d'une histoire de la biologie

Par Jean Rostand. Pp. $258+14$ plates. Libr. Gallimard, 1945.) 140 franes.

$T$ HIS sketch summarizes the history of biology from the middle of the seventeenth century up to the present day, the term biology being used in a restricted sense to include only the fundamental problems of organic life, namely, the genesis of life ; the formation of the organism; and the evolution of species. While the overall treatment of the subject is chronological, its detailed development is traced in relation to the men of science responsible for major advances. The following examples, selected from the twenty-three chapter headings, suffice to indicate the scope and treatment: Redi, Leeuwenhoek and the microscope ; the experiments of Lazaro Spallanzani; Cuvier and the science of fossils ; Charles Darwin and the origin of species; recent advances in biology. Short biographies of the naturalists who have made major contributions to biological thought are included in the chapters dealing with their work. The book concludes with a table setting out the principal dates in the history of biology, a brief bibliography and an index of names cited. It should serve as a valuable introduction to the subject for university students in biology. 